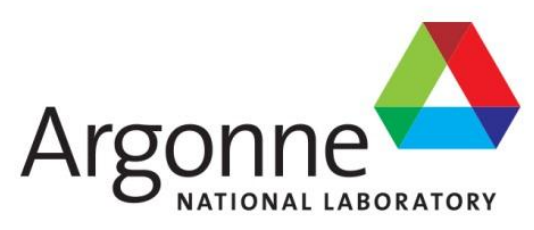

ANL/CSE-13/26

\title{
Dual Column Tracer Experimental Results
}

Chemical Science and Engineering Division 


\begin{abstract}
About Argonne National Laboratory
Argonne is a U.S. Department of Energy laboratory managed by UChicago Argonne, LLC under contract DE-AC02-06CH11357. The Laboratory's main facility is outside Chicago, at 9700 South Cass Avenue, Argonne, Illinois 60439. For information about Argonne and its pioneering science and technology programs, see www.anl.gov.
\end{abstract}

\title{
DOCUMENT AVAILABILITY
}

Online Access: U.S. Department of Energy (DOE) reports produced after 1991 and a growing number of pre-1991 documents are available free via DOE's SciTech Connect (http://www.osti.gov/scitech/)

Reports not in digital format may be purchased by the public from the National Technical Information Service (NTIS):

U.S. Department of Commerce

National Technical Information Service

5301 Shawnee Rd

Alexandra, VA 22312

www.ntis.gov

Phone: (800) 553-NTIS (6847) or (703) 605-6000

Fax: (703) 605-6900

Email: orders@ntis.gov

Reports not in digital format are available to DOE and DOE contractors from the Office of Scientific and Technical Information (OSTI):

U.S. Department of Energy

Office of Scientific and Technical Information

P.O. Box 62

Oak Ridge, TN 37831-0062

www.osti.gov

Phone: (865) 576-8401

Fax: (865) 576-5728

Email: reports@osti.gov

\footnotetext{
Disclaimer

This report was prepared as an account of work sponsored by an agency of the United States Government. Neither the United States Government nor any agency thereof, nor UChicago Argonne, LLC, nor any of their employees or officers, makes any warranty, express or implied, or assumes any legal liability or responsibility for the accuracy, completeness, or usefulness of any information, apparatus, product, or process disclosed, or represents that its use would not infringe privately owned rights. Reference herein to any specific commercial product, process, or service by trade name, trademark, manufacturer, or otherwise, does not necessarily constitute or imply its endorsement, recommendation, or favoring by the United States Government or any agency thereof. The views and opinions of document authors expressed herein do not necessarily state or reflect those of the United States Government or any agency thereof, Argonne National Laboratory, or UChicago Argonne, LLC.
} 


\section{Dual Column Tracer Experimental Results}

by

Amanda J. Youker, Dominique C. Stepinski, Vivian S. Sullivan, Sergey Chemerisov, and George F. Vandegrift

Chemical Science and Engineering Division, Argonne National Laboratory

prepared for

U.S. Department of Energy, National Nuclear Security Administration, Office of Defense Nuclear Nonproliferation

April 30, 2013 



\section{CONTENTS}

INTRODUCTION

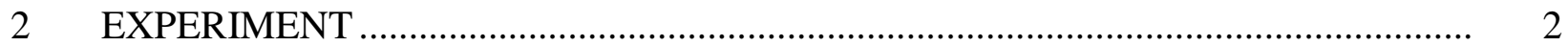

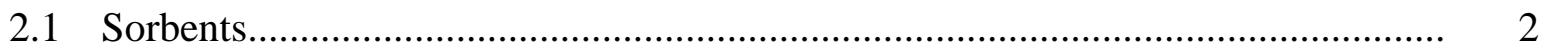

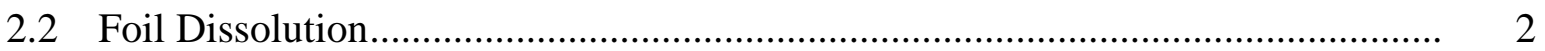

2.3 Gamma Counting .................................................................................... 2

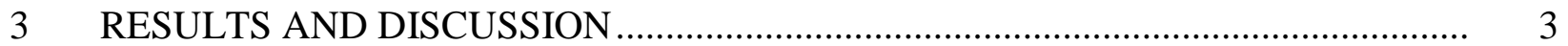

3.1 Initial Mo Recovery Column ........................................................................... 3

3.2 Concentration Column ................................................................................ 4

3.3 Concentration Column Results ...................................................................... 5

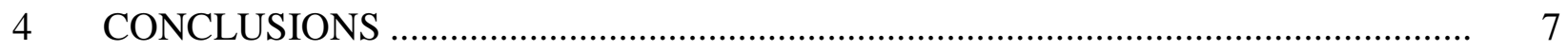

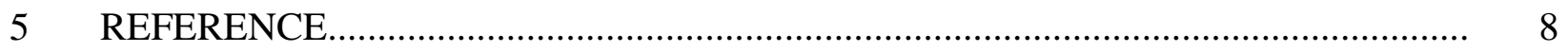

\section{TABLES}

1 List of Isotope Activities with Decay Calculations Back to End of Irradiation and Isotopic Distributions after Initial Recovery Column....................................... 3

2 Concentration Column Design for Loading 99.9\% of Mo in 60 min, Utilizing S40 Sorbent.

3 Direct Scale-Down Concentration Column Design Concentration Column Experiment with the Linac Irradiated Target........................................................... 5

$4 \quad$ Mo Recovery Results, Counted on March 19, 2013, 8:00 PM................................ 5

$5 \quad$ Partitioning of $\mathrm{U}$ and Fission Products between Concentration Column Process Streams

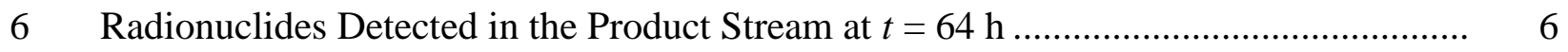




\section{DUAL COLUMN TRACER EXPERIMENTAL RESULTS}

\section{INTRODUCTION}

Argonne National Laboratory (Argonne) is assisting Morgridge Institute for Research (MIR) in their efforts to develop SHINE (Subcritical Hybrid Intense Neutron Emitter), which is an accelerator-driven process that will use a uranyl-sulfate solution for the production of Mo-99. An integral part of the process is the development of a dual column for the recovery of Mo-99 from an irradiated target solution. Argonne has collected data from batch studies and small-scale column experiments to input into VERSE (Versatile Reaction Separation), which was developed by Dr. Linda Wang at Purdue University, to design large-scale separation processes using data obtained on a much smaller scale. Plant-scale column designs have been generated for the initial Mo-recovery column and the concentration column, which has been added to reduce strip volume prior to entry into the LEU-Modified Cintichem purification process. Direct downscale column experiments have been performed using $1 \mathrm{~g}$ of linac-irradiated DU (depleted uranium) foils as a spike for a uranyl-sulfate solution. The strip solution from the initial recovery column was used as a spike for a $\mathrm{pH} 2$ sodium nitrate solution, which served as the feed solution for the concentration column. 


\section{EXPERIMENT}

\subsection{SORBENTS}

A 110 -micron particle size pure titania sorbent with 60 - $\AA$ pores was used for the initial recovery column, which was a $0.66 \mathrm{~cm}$ ID (internal diameter) $\times 5 \mathrm{~cm} L$ (length) column. Approximately $152 \mathrm{~mL}$ of a $130 \mathrm{~g}$-U/L uranyl-sulfate solution with a stable Mo concentration of $2.4 \times 10^{-3} \mathrm{mM}$ and $1 \mathrm{~g}$ of dissolved linac-irradiated foils was passed through the column at a flow rate of $1.4 \mathrm{~mL} / \mathrm{min}$. A 40 -micron particle size pure titania sorbent with $60-\AA$ pores was used for the concentration column, which was a $1 \mathrm{~cm}$ ID $\times 1.5 \mathrm{~cm} L$ column. The SHINE concentration column design was tested using the product solution from a downsized Mo-recovery column as a spike because a column small enough to handle $52 \mathrm{~mL}$ of solution could not be packed. Approximately $1470 \mathrm{~mL}$ of a pH $2 \mathrm{NaNO}_{3}$ solution containing $2.4 \times 10^{-2}$ $\mathrm{mM}$ stable Mo spiked with $52 \mathrm{~mL}$ of strip solution generated from the initial recovery column was loaded onto the column at a flow rate of $24.5 \mathrm{~mL} / \mathrm{min}$. Mo was recovered after passing $20 \mathrm{CVs}$ (column volumes) of $1 \mathrm{M} \mathrm{NH}_{4} \mathrm{OH}$ heated to $70^{\circ} \mathrm{C}$ at a flow rate of $4 \mathrm{~mL} / \mathrm{min}$ through the column.

\subsection{FOIL DISSOLUTION}

After cooling overnight, the foils were removed from the linac facility. The doubleencapsulated Al-clad target was cut open and foils were removed. Three small irradiated-DU foils totaling $1 \mathrm{~g}$ of uranium were dissolved in nitric acid. The foils were dissolved in $20 \mathrm{~mL}$ of $6 \mathrm{M} \mathrm{HNO}_{3}$ using a hot water bath and a condenser filled with ice and acetone. Dissolution took approximately $3 \mathrm{~h}$ because the nitric acid concentration was kept low to minimize the amount of nitrate left in solution. After dissolution, the uranyl-nitrate solution was brought to dryness to drive off nitrate. The solid uranium was re-dissolved in $250 \mathrm{~mL}$ of a $130 \mathrm{~g}$-U/L uranyl-sulfate solution containing $2.4 \times 10^{-3} \mathrm{mM}$ stable Mo with a final $\mathrm{pH}$ of $\sim 1$. The final solution was used as the feed solution for the initial recovery column. It was passed through the 110-micron particle size titania column over a period of $2 \mathrm{~h}$.

\subsection{GAMMA COUNTING}

Samples were counted at a distance using a Germanium detector. The U-237 content was very high due to the $\gamma-\mathrm{n}$ reaction on $\mathrm{U}-238$, which makes it difficult to analyze fission products with lower energies. U-237 summation peaks make it difficult to accurately measure activities for certain fission products, so as a result, irradiation of low enriched uranium (LEU) solutions in the future will provide more meaningful sources of tracers planned for use in column experiments and clean-up studies using centrifugal contactors for the entire UREX process. 


\section{RESULTS AND DISCUSSION}

\subsection{INITIAL Mo RECOVERY COLUMN}

Approximately $152 \mathrm{~mL}$ of a $130 \mathrm{~g}$-U/L uranyl-sulfate solution was loaded onto a $0.66 \mathrm{~cm} \mathrm{ID} \times 5 \mathrm{~cm} L$ titania column in the up-flow direction at a flow rate of $1.3 \mathrm{~mL} / \mathrm{min}$. The column was subsequently washed with $10 \mathrm{CVs}$ of $0.1 \mathrm{M} \mathrm{H}_{2} \mathrm{SO}_{4}$ in the up-flow direction, $5 \mathrm{CVs}$ of $\mathrm{H}_{2} \mathrm{O}$ in the up-flow direction, $30 \mathrm{CVs}$ of $0.1 \mathrm{M} \mathrm{NH}_{4} \mathrm{OH}$ heated to $70^{\circ} \mathrm{C}$ in the down-flow direction at $0.7 \mathrm{~mL} / \mathrm{min}$, and $5 \mathrm{CVs}$ of $\mathrm{H}_{2} \mathrm{O}$ in the up-flow direction. Approximately $260 \mu \mathrm{Ci}$ Mo-99 was produced during irradiation, and $87 \%$ Mo was recovered in the strip solution. Iodine was a major contaminant found in the Mo product. Table 1 shows the results for various isotopes produced. Errors associated with these results are $\pm 10 \%$, which is why some of the percentages found in each fraction exceed 100\%. Results suggest that almost all of the Sr-91, Ru-103, Rh105, Ce-141, Ce-143, Nd-147, and Pm-151 produced do not adsorb on titania and are found in the effluent and acid wash, which contains $1 \mathrm{CV}$ of column effluent. SHINE can expect these fission products to be present in the target solution prior to clean-up. Isotopes that essentially remain adsorbed on the titania column after Mo-recovery include $\mathrm{Nb}, \mathrm{Zr}$, and $\mathrm{Sb}$ isotopes, and

\section{TABLE 1 List of Isotope Activities with Decay Calculations Back to End of Irradiation (March 26, 2013, at 6:00 PM) and Isotopic Distributions after Initial Recovery Column}

\begin{tabular}{|c|c|c|c|c|c|c|c|c|}
\hline Isotope & $\begin{array}{c}\text { Feed } \\
\text { Activity } \\
(\mu \mathrm{Ci})\end{array}$ & $\begin{array}{l}\text { Half-Life } \\
\text { (h) }\end{array}$ & $\begin{array}{c}\% \text { in } \\
\text { Effluent }\end{array}$ & $\begin{array}{l}\% \text { in } \\
\text { Acid } \\
\text { Wash }\end{array}$ & $\begin{array}{c}\% \text { in } \\
\text { Water } \\
\text { Wash \#1 }\end{array}$ & $\begin{array}{l}\% \text { in } \\
\text { Strip }\end{array}$ & $\begin{array}{c}\% \text { in } \\
\text { Water } \\
\text { Wash \#2 }\end{array}$ & $\begin{array}{c}\% \\
\text { Remaining } \\
\text { on Column }\end{array}$ \\
\hline Sr-91 & 1233.5 & 9.6 & 95.1 & 0.5 & 0.0 & 0.0 & 0.0 & 4.4 \\
\hline $\mathrm{Nb}-95$ & 1.0 & 840.0 & 10.1 & 0.0 & 0.2 & 0.0 & 0.1 & 89.6 \\
\hline Zr-95 & 9.5 & 1536.0 & 3.3 & 0.1 & 0.0 & 0.0 & 0.0 & 96.5 \\
\hline Nb-97 & 40.1 & 1.2 & 3.4 & 0.1 & 0.0 & 0.1 & 0.0 & 96.3 \\
\hline Zr-97 & 759.0 & 16.8 & 1.7 & 0.3 & 0.0 & 0.4 & 0.0 & 97.6 \\
\hline Мо-99 & 260.9 & 66.6 & 0.0 & 0.0 & 0.0 & 87.0 & 0.2 & 12.8 \\
\hline Ru-103 & 3.7 & 936.0 & 100.4 & 3.1 & 0.6 & 0.0 & 0.0 & 0.0 \\
\hline Rh-105 & 231.0 & 4.6 & 100.2 & 1.9 & 0.3 & 1.8 & 0.0 & 0.0 \\
\hline Sb-127 & 27.4 & 93.6 & 3.8 & 0.3 & 0.0 & 13.7 & 0.1 & 82.1 \\
\hline Te-131m & 89.5 & 31.2 & 2.1 & 3.2 & 0.6 & 26.5 & 0.1 & 67.5 \\
\hline I-131 & 25.3 & 192.0 & 1.2 & 0.4 & 0.2 & 97.0 & 0.1 & 1.1 \\
\hline I-132 & 101.8 & 2.4 & 0.9 & 1.6 & 0.5 & 28.2 & 0.1 & 68.7 \\
\hline Тe-132 & 173.3 & 76.8 & 2.8 & 1.9 & 1.0 & 53.0 & 0.1 & 41.2 \\
\hline I-133 & 495.0 & 20.4 & 0.2 & 0.0 & 0.0 & 109.9 & 0.1 & 0.0 \\
\hline Ba-140 & 64.1 & 312.0 & 99.9 & 1.4 & 0.1 & 0.6 & 0.0 & 0.0 \\
\hline La-140 & 37.1 & 40.8 & 74.4 & 1.2 & 0.1 & 0.9 & 0.0 & 23.5 \\
\hline Ce-141 & 17.6 & 768.0 & 106.6 & 0.9 & 0.0 & 0.0 & 0.0 & 0.0 \\
\hline Ce-143 & 346.6 & 33.6 & 107.5 & 1.0 & 0.0 & 0.3 & 0.0 & 0.0 \\
\hline Nd-147 & 18.2 & 264.0 & 96.4 & 1.0 & 0.0 & 2.9 & 0.0 & 0.0 \\
\hline Pm-151 & 74.2 & 288.0 & 100.8 & 1.0 & 0.0 & 0.0 & 0.0 & 0.0 \\
\hline
\end{tabular}


$40-60 \%$ of Te isotopes remain bound to the titania column. Nearly all of the I-131 and I-133 coeluted with the Mo-product with an additional 30\% I-132. Not all of the I-132 eluted with other iodine isotopes in the Mo-product solution because it is a decay product of Te-132, and $~ 40 \%$ Te-132 remained on the column post Mo-recovery.

Results from the irradiated DU foil experiments suggest that iodine will be a major contaminant in the Mo-product stream. However, additional steps have been added to the LEU-Modified Cintichem process to handle large amounts of iodine. The first step includes an additional contact step with $1 \mathrm{M} \mathrm{HNO}_{3}$ to promote formation of volatile iodine, which can be trapped, and an isotopic exchange step to convert any iodate or iodine to iodide. These results contradict previous Van de Graaff iodine speciation results, which showed that more than 95\% of the iodine was present as iodide after irradiation. Nonetheless, the mini-SHINE experiments will provide vital data under conditions much more representative of the SHINE operation regarding iodine behavior during irradiation, cooling, Mo separation, and Mo recovery.

\subsection{CONCENTRATION COLUMN}

After a 2-h Mo loading process onto a S110 packed column, and then stripping Mo from the column with $0.1 \mathrm{M} \mathrm{NaOH}$ at $70^{\circ} \mathrm{C}$, the Mo-product-solution from the initial recovery column is then reduced using a concentration column. Before loading onto the concentration column, the Mo product is acidified, resulting in approximately $24 \mathrm{~L}$ of a solution containing $0.1 \mathrm{M} \mathrm{NaNO}_{3}$ and $2.4 \times 10^{-2} \mathrm{mM}$ Mo at $\mathrm{pH} 2$. The column design for concentrating the Mo product is a $4 \mathrm{~cm}$ ID $\times 1.5 \mathrm{~cm} L$ column utilizing S40 sorbent. ${ }^{1}$ The column was designed to load the product in $60 \mathrm{~min}$ at $80^{\circ} \mathrm{C}$, resulting in a flow rate of $392 \mathrm{~mL} / \mathrm{min}$ and velocity of $31.2 \mathrm{~cm} / \mathrm{min}$ (Stepinski et al. 2012). The details of the concentration column process design are outlined in Table 2. After loading, the column is washed with $10 \mathrm{CVs}$ of $0.01 \mathrm{M} \mathrm{HNO}_{3}$, followed by $10 \mathrm{CVs}$ of water, and stripped with $1 \mathrm{M} \mathrm{NH}_{4} \mathrm{OH}$ at $70^{\circ} \mathrm{C}$.

The column process utilized for the concentration-column experiment was a direct scaledown of the design summarized in Table 2. For the lab-scale experiment, a $1 \mathrm{~cm} \mathrm{ID} \times 1.5 \mathrm{~cm} \mathrm{~L}$ $\mathrm{S} 40$ column was loaded at $31.2 \mathrm{~cm} / \mathrm{min}$ at $80^{\circ} \mathrm{C}$. Details of the lab-scale column process are summarized in Table 3 . The feed solution $(1470 \mathrm{~mL})$ utilized in this experiment had a composition of $0.1 \mathrm{M} \mathrm{NaNO}_{3}, 0.0064 \mathrm{M} \mathrm{HNO}_{3}(\mathrm{pH} 2.2)$, and $2.4 \times 10^{-2} \mathrm{mM}$ Mo. The feed

TABLE 2 Concentration Column Design for Loading 99.9\% of Mo in $60 \mathrm{~min}$, Utilizing S40 Sorbent

\begin{tabular}{ccccccccc}
\hline $\begin{array}{c}\text { Column } \\
\text { ID } \\
(\mathrm{cm})\end{array}$ & $\begin{array}{c}\text { Velocity } \\
(\mathrm{cm} / \mathrm{min})\end{array}$ & $\begin{array}{c}\mathrm{MTZ}_{0.1 \%} \\
(\mathrm{~cm})\end{array}$ & $\begin{array}{c}\text { Column } \\
\text { Length } \\
(\mathrm{cm})\end{array}$ & $\begin{array}{c}\text { Column } \\
\text { Volume } \\
(\mathrm{mL})\end{array}$ & $\begin{array}{c}\text { Sorbent } \\
\text { Weight } \\
(\mathrm{g})\end{array}$ & $\begin{array}{c}\Delta P \\
(\mathrm{~atm})\end{array}$ & $\begin{array}{c}\text { Mo-99/Sorbent } \\
\text { Mass } \\
(\mathrm{Ci} / \mathrm{g})\end{array}$ & $\begin{array}{c}\text { Strip } \\
\text { Volume } \\
(\mathrm{mL})\end{array}$ \\
\hline 4 & 31.20 & 1.11 & 1.5 & 19 & 24 & 0.32 & 163.45 & 301.6 \\
\hline
\end{tabular}

1 ZirChrom Separations, Inc. 
TABLE 3 Direct Scale-Down Concentration Column Design Concentration Column Experiment with the Linac Irradiated Target

\begin{tabular}{|c|c|c|c|c|c|c|c|c|}
\hline $\begin{array}{l}\text { Column } \\
\text { ID } \\
(\mathrm{cm})\end{array}$ & $\begin{array}{l}\text { Velocity } \\
(\mathrm{cm} / \mathrm{min})\end{array}$ & $\begin{array}{c}\mathrm{MTZ}_{0.1 \%} \\
\quad(\mathrm{~cm})\end{array}$ & $\begin{array}{c}\text { Column } \\
\text { Length } \\
(\mathrm{cm})\end{array}$ & $\begin{array}{c}\text { Column } \\
\text { Volume } \\
(\mathrm{mL})\end{array}$ & $\begin{array}{c}\text { Sorbent } \\
\text { Weight } \\
(\mathrm{g})\end{array}$ & $\begin{array}{c}\Delta P \\
(\mathrm{~atm})\end{array}$ & $\begin{array}{c}\text { Flow Rate } \\
(\mathrm{mL} / \mathrm{min})\end{array}$ & $\begin{array}{c}\text { Feed } \\
\text { Volume } \\
(\mathrm{mL})\end{array}$ \\
\hline 1 & 31.20 & 1.11 & 1.50 & 1.18 & 1.48 & 0.32 & 24.50 & 1470 \\
\hline
\end{tabular}

solution was loaded using the ÄKTA LC (GE Healthcare Life Sciences) in 60 min at a rate of $24.5 \mathrm{~mL} / \mathrm{min}$. Following loading, the column was washed with $11.8 \mathrm{~mL}(10 \mathrm{BV})$ of $0.01 \mathrm{M}$ $\mathrm{HNO}_{3}$ and $\mathrm{H}_{2} \mathrm{O}$ at $31.2 \mathrm{~cm} / \mathrm{min}(24.5 \mathrm{~mL} / \mathrm{min})$. The column was stripped with $3 \times 14.3 \mathrm{~mL}$ $(3 \times 12 \mathrm{CV})$ of $1 \mathrm{M} \mathrm{NH}_{4} \mathrm{OH}$ at $70^{\circ} \mathrm{C}$ at a rate of $5 \mathrm{~cm} / \mathrm{min}(4 \mathrm{~mL} / \mathrm{min})$.

\subsection{CONCENTRATION COLUMN RESULTS}

The gamma counting results indicate that Mo-99 was not present in the effluent or the acid and water washes, suggesting that all the Mo was loaded on the column. The results indicate that $88.5 \% \pm 10 \%$ of Mo was stripped from the column. Mo-99 recovery ranged from $103.6 \%$ to $87.1 \%$ for three different sample counts over a period of $72 \mathrm{~h}$. However, the dead time on strip 1, was $>80 \%$ for all counts and could affect the results. The results for samples counted on March 19, 2013, 8:00 PM are summarized in Table 4.

Partitioning of actinides and fission products between process streams was determined using gamma counting (Table 5). Iodine partitioned in the strips, along with the Mo product

TABLE 4 Mo Recovery Results, Counted on March 19, 2013, 8:00 PM

\begin{tabular}{lclc}
\hline \multicolumn{1}{c}{ Stream } & $\begin{array}{c}\text { Volume } \\
(\mathrm{BV})\end{array}$ & $\begin{array}{c}\text { Mo-99 } \\
(\mu \mathrm{Ci})\end{array}$ & $\begin{array}{c}\text { Mo-99 } \\
(\%)\end{array}$ \\
\hline Feed & & $1.91 \mathrm{E}+02$ & \\
Eluent & & $\mathrm{ND}^{\mathrm{a}}$ & \\
Wash 0.01 M HNO 3 & 10 & $\mathrm{ND}$ & \\
Wash, water & 10 & $\mathrm{ND}$ & \\
Strip, fraction 1 & 12 & $1.56 \mathrm{E}+02$ & 81.6 \\
Strip, fraction 2 & 12 & $1.04 \mathrm{E}+01$ & 5.5 \\
Strip, fraction 3 & 12 & $2.83 \mathrm{E}+00$ & 1.5 \\
& & & \\
Mo recovered (strips) & 36 & $1.69 \mathrm{E}+02$ & 88.5 \\
\hline
\end{tabular}

a ND = "not detected." 
TABLE 5 Partitioning of $\mathbf{U}$ and Fission Products between Concentration Column Process Streams

\begin{tabular}{|c|c|c|c|c|c|c|c|c|c|c|c|c|c|c|c|c|}
\hline \multirow[t]{2}{*}{ Isotope } & \multirow{2}{*}{$\begin{array}{c}\text { Half-life } \\
\text { days }\end{array}$} & \multirow{2}{*}{$\begin{array}{l}\text { Feed } \\
\mu \mathrm{Ci}\end{array}$} & \multicolumn{2}{|c|}{ Eluent } & \multicolumn{2}{|c|}{ Acid Wash } & \multicolumn{2}{|c|}{ Water Wash } & \multicolumn{2}{|c|}{ Strip 1} & \multicolumn{2}{|c|}{ Strip 2} & \multicolumn{2}{|c|}{ Strip 3} & \multicolumn{2}{|c|}{ Total } \\
\hline & & & $\mu \mathrm{Ci}$ & $\%$ & $\mu \mathrm{Ci}$ & $\%$ & $\mu \mathrm{Ci}$ & $\%$ & $\mu \mathrm{Ci}$ & $\%$ & $\mu \mathrm{Ci}$ & $\%$ & $\mu \mathrm{Ci}$ & $\%$ & $\mu \mathrm{Ci}$ & $\%$ \\
\hline $\mathrm{I}-133$ & 0.9 & $4.69 E+02$ & $8.82 E+00$ & 1.9 & $8.32 \mathrm{E}-02$ & 0.0 & $1.68 \mathrm{E}-02$ & 0.0 & $1.13 E+02$ & 24.1 & $7.74 \mathrm{E}+01$ & 16.5 & $2.83 E+01$ & 6.0 & $2.28 \mathrm{E}+02$ & 48.6 \\
\hline Sb-127 & 3.9 & $3.48 \mathrm{E}+00$ & ND & & ND & & ND & & $1.50 \mathrm{E}-01$ & 4.3 & $1.23 \mathrm{E}-01$ & 3.5 & $5.73 \mathrm{E}-02$ & 1.6 & 3.30E-01 & 9.5 \\
\hline Te-131m & 1.3 & $4.44 \mathrm{E}+01$ & $5.20 \mathrm{E}+00$ & 11.7 & 2.37E-02 & 0.1 & $2.03 \mathrm{E}-02$ & 0.0 & $1.18 \mathrm{E}+00$ & 2.7 & $1.31 \mathrm{E}+00$ & 3.0 & 4.39E-01 & 1.0 & $8.18 \mathrm{E}+00$ & 18.4 \\
\hline Te-132 & 3.2 & $7.70 E+01$ & $4.40 E+00$ & 5.7 & $5.27 \mathrm{E}-02$ & 0.1 & $2.04 \mathrm{E}-02$ & 0.0 & $3.27 E+00$ & 4.3 & $3.17 E+00$ & 4.1 & $1.57 \mathrm{E}+00$ & 2.0 & $1.25 \mathrm{E}+01$ & 16.2 \\
\hline U-237 & 6.8 & ND & $1.47 E+00$ & & $3.00 \mathrm{E}-02$ & & $1.18 \mathrm{E}-02$ & & ND & & ND & & ND & & $1.51 \mathrm{E}+00$ & \\
\hline Zr-97 & 0.70 & $3.41 \mathrm{E}+00$ & $1.53 \mathrm{E}+00$ & 44.8 & 6.96E-03 & 0.2 & ND & & ND & & $1.64 \mathrm{E}-01$ & 4.8 & $0.00 \mathrm{E}+00$ & 0.0 & $1.70 \mathrm{E}+00$ & 49.9 \\
\hline
\end{tabular}

$(\sim 50 \%)$ and the remaining iodine, was either lost to the vapor phase or left on the sorbent.

Approximately $10 \%$ of the antimony was found in the Mo product, and the rest likely remained on the sorbent. Similarly, approximately $10 \%$ of the tellurium was found in the Mo product, and $>80 \%$ likely remained on the sorbent. A large fraction of the zirconium $(\sim 45 \%)$ was found in the effluent, and $\sim 50 \%$ likely remained on the sorbent. U-237 was detected in eluent and washes only; none was detected in the strip fractions.

$\mathrm{I}-131, \mathrm{I}-132, \mathrm{Nb}-97$, and $\mathrm{Xe}-135$ were detected in the process streams at $t=64 \mathrm{~h}$. Their activities were not corrected to $t=0$ since they are growing in from their parent radionuclides. Only I-131, I-132, and Xe-135 were detected in the Mo product stream; their activities are presented as $\mu \mathrm{Ci} / \mathrm{mCi} \mathrm{Mo}-99$ at $t=64 \mathrm{~h}$ (Table 6).

\section{TABLE 6 Radionuclides Detected in the Product Stream} at $t=64 \mathrm{~h}$

\begin{tabular}{|c|c|c|c|c|c|}
\hline Isotope & $\begin{array}{c}\text { Half-life } \\
\text { (days) }\end{array}$ & Parent & $\begin{array}{c}\text { Half-life } \\
\text { (days) }\end{array}$ & $\begin{array}{l}\text { Total Activity } \\
(\mu \mathrm{Ci}) \text { at } \\
\text { T-count, } 64 \mathrm{~h}\end{array}$ & $\begin{array}{c}\mu \mathrm{Ci} / \mathrm{mCi} \\
\mathrm{Mo}-99 \\
\end{array}$ \\
\hline $\mathrm{I}-131$ & 8.02 & $\mathrm{Te}-131 \mathrm{~m}$ & 1.25 & $1.27 \mathrm{E}+01$ & 76 \\
\hline I-132 & 0.1 & Te-132 & 3.25 & $4.05 \mathrm{E}+00$ & 24 \\
\hline $\mathrm{Nb}-97$ & 0.05 & $\mathrm{Zr}-97$ & 0.7 & $\mathrm{ND}^{\mathrm{a}}$ & \\
\hline Xe-135 & 0.38 & $\mathrm{I}-135$ & 0.28 & $1.91 \mathrm{E}+01$ & 115 \\
\hline
\end{tabular}

a $\quad \mathrm{ND}=$ "not detected." 


\section{CONCLUSIONS}

Results from the dual-column Mo separation and recovery process using linac-irradiated DU foils as a spike show that $87 \% \pm 10 \%$ Mo was recovered from the initial recovery column. Iodine was the major contaminant found in the Mo product, and about $15 \% \mathrm{Sb}$ and $30 \%$ Te were found as well. Modifications have been made to the LEU-Modified Cintichem purification process to remove the iodine from the Mo product, and the current process can already handle removal of $\mathrm{Sb}$ and Te. The mini-SHINE experiments will provide data that are more representative of the SHINE system, where fission products are generated in solution rather than in a foil; however, these foil experiments suggest that iodine contamination in the Mo product is highly likely.

Verification studies for a $4 \mathrm{~cm} \mathrm{ID} \times 1.5 \mathrm{~cm} \mathrm{~L} \mathrm{S40} \mathrm{99.9 \%} \mathrm{Mo} \mathrm{loading} \mathrm{column} \mathrm{design} \mathrm{for}$ concentration of the Mo product indicate that the all of the Mo in the feed solution was loaded on the column. Approximately $88.5 \% \pm 10 \%$ Mo was recovered from the concentration column. However, the dead time for strip 1 was $>80 \%$, which could have affected the results. Partitioning of $\mathrm{U}$ and fission products between different process streams indicates that a fraction of $\mathrm{Te}, \mathrm{Sb}$, and $\mathrm{Zr}$ partitions in the Mo product stream, and the majority remains on the sorbent. Approximately 50\% of the iodine in feed was found in the Mo product, and the rest was either lost to the vapor phase or left on the sorbent. Uranium was detected in effluent and washes only; none was detected in the Mo product. Overall, this column design achieved excellent loading and provides an additional purification step for Mo product. Stripping results call for additional verification and optimization. Improvements can be made based on the results that we have obtained to date, such as minimizing the dead volume in the system and decreasing the amount of U-237 to reduce gamma counting errors. 


\section{REFERENCE}

Stepinski, D.C., A.J. Youker, and G.F. Vandegrift, 2012, Plant-scale Concentration Column Designs for SHINE Target Solution, Argonne National Laboratory, September. 



\section{Argonne}

\section{Chemical Science and Engineering Division}

Argonne National Laboratory

9700 South Cass Avenue, Bldg. 205

Argonne, IL 60439-4837

www.anl.gov

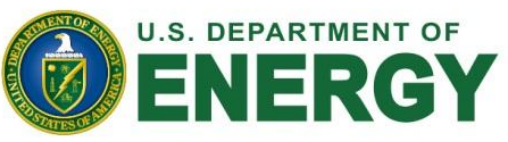

Argonne National Laboratory is a U.S. Department of Energy

laboratory managed by UChicago Argonne, LLC 